\title{
PENERAPAN TEKNOLOGI BUDIDAYA DAN SHOW OFF PRODUK MAKANAN BERBAHAN SAYURAN DAN DAMPAKNYA PADA SISWA SDN KARANGSALAM KECAMATAN KEDUNGBANTENG KABUPATEN BANYUMAS JAWA TENGAH
}

\author{
Sapto Nugroho Hadi ${ }^{*}$, Ahadiyat Yugi Rahayu ${ }^{1}$, Okti Herliana ${ }^{1}$ \\ ${ }^{1}$ Program Studi Agroteknologi, Fakultas Pertanian, Universitas Jenderal Soedirman, Purwokerto, Indonesia \\ *Penulis Korespodensi: snhadi@gmail.com
}

\begin{abstract}
Abstrak
Permasalahan di SDN Karangsalam, yaitu (1). Pihak sekolah memiliki komitmen menjadi sekolah adiwiyata, namun belum memiliki program pendukung, (2). Pihak sekolah prihatin dengan minimnya pengetahuan siswa terhadap ragam jenis sayur dan manfaatnya, (3). Pola konsumsi makanan harian siswa yang cenderung instan, minim sayur dan gizi tidak berimbang, dan (4). Sekolah berada di lingkungan cukup padat penduduk yang belum memanfaatkan lingkungan rumahnya untuk kegiatan budidaya tanaman sayuran. Kegiatan ini bertujuan menerapkan teknologi budidaya tanaman sayuran dengan sistem demonstrasi dan plot (demplot), melakukan transfer pengetahuan beragam jenis sayur dan manfaatnya, dan show off produk makanan berbahan sayuran. Metode yang dilaksanakan, yaitu demplot dan pelatihan budidaya tanaman sayuran, transfer pengetahuan tentang beragam jenis sayur dan manfaatnya, serta show off produk makanan berbahan sayuran. Hasilnya kegiatan ini dapat meningkatkan pengetahuan siswa terhadap budidaya sayuran dengan teknik vertikultur dari $0 \%$ menjadi $71 \%$, meningkatkan pengetahuan siswa terhadap ragam jenis sayuran dari $0 \%$ menjadi $92 \%$, meningkatkan kemampuan siswa menjawab dengan benar manfaat sayuran bagi kesehatan dari $0 \%$ menjadi $62 \%$, meningkatkan ketertarikan siswa dalam budidaya tanaman sayuran dari $33 \%$ menjadi $46 \%$, meningkatkan kesukaan siswa terhadap makanan berbahan sayuran dari $92 \%$ menjadi $100 \%$, meningkatkan frekuensi harian konsumsi siswa terhadap makanan berbahan sayuran dari $42 \%$ menjadi $71 \%$.
\end{abstract}

Kata kunci: SDN Karangsalam, Pengabdian Kepada Masyarakat

\begin{abstract}
Problem in SDN Karangsalam: (1). The school has a commitment to become adiwiyata schools, but there is no supporting program, (2). Students' lack of knowledge of vegetables type and their benefits, (3). Daily food consumption of students tend to be instant, lack of vegetables, and (4). The community around the school has not utilized the home environment for vegetable cultivation. This activity aimed to implement vegetable cultivation with demonstration and plots (demplot), transfer knowledge of vegetables type and their benefits, and show off vegetable-based food products. The methods were implemented: demplot and training in vegetable cultivation, transfer knowledge of vegetables type and their benefits, and show off vegetable-based food products. The result showed increasing: students' knowledge of verticulture techniques for vegetable cultivation from $0 \%$ to $71 \%$, students' knowledge of vegetables type from $0 \%$ to $92 \%$, students' ability for answering the benefits of vegetables from $0 \%$ to $62 \%$, student interest in vegetable cultivation from $33 \%$ to $46 \%$, students' preference for vegetablebased foods from $92 \%$ to $100 \%$, the frequency of daily consumption of vegetable-based foods from $42 \%$ to $71 \%$.
\end{abstract}

Keywords: SDN Karangsalam, Community service

\section{PENDAHULUAN}

Sekolah Dasar Negeri (SDN) Karangsalam terletak terletak di lingkungan cukup padat penduduk di wilayah Rukun Warga 03 Desa Karangsalam Kidul Kecamatan Kedungbanteng Kabupaten Banyumas Provinsi Jawa Tengah. SDN Karangsalam merupakan hasil peleburan SDN 1 Karangsalam dan SDN 2
Karangsalam, dengan total jumlah siswa 193 orang dan guru 12 orang.

Permasalahan yang dialami SDN Karangsalam yang menjadikan kegiatan pengabdian kepada masyarakat (PKM) penting dilaksanakan di tempat ini, yaitu (1). Pihak sekolah memiliki komitmen menjadi salah satu 
sekolah adiwiyata (sekolah berbasis lingkungan hidup), namun program kegiatan mengarah ke sana belum ada, (2). Pihak sekolah memiliki keprihatinan tentang minimnya pengetahuan siswa terhadap ragam jenis sayur dan manfaatnya, (3). Pola konsumsi makanan harian siswa yang cenderung instan, minim sayur dan gizi tidak berimbang karena kebiasaan orangtua siswa serba praktis dalam menyiapkan makanan untuk anaknya, dan (4). Sekolah berada di lingkungan cukup padat penduduk yang berdasarkan hasil pengamatan tim belum memanfaatkan lingkungan rumahnya untuk kegiatan budidaya tanaman sayuran.

Sejumlah kegiatan PKM pernah dilakukan terkait penerapan budidaya tanaman pertanian di lingkungan sekolah dan secara positif berdampak pada siswa dan sekolah. Hasil kegiatan PKM yang dilakukan Kartini et al. (2015) menunjukkan kegiatan berkebun sayur di sekolah dapat meningkatkan frekuensi konsumsi sayur dan buah pada siswa. Kegiatan PKM yang dilakukan Hadi et al. (2017) juga menunjukkan kecenderungan yang sama. Penerapan teknologi berkebun sayur di lingkungan sekolah dapat meningkatkan pengetahuan dan keterampilan siswa dalam hal budidaya tanaman sayur, ragam jenis sayur dan manfaatnya, serta ketertarikan siswa terhadap makanan berbahan sayur.

Terkait dengan upaya untuk mendorong masyarakat sekitar sekolah melakukan kegiatan budidaya tanaman sayur, beberapa PKM menunjukkan bahwa aplikasi kegiatan bertanam sayur dan buah sangat mungkin dilakukan dan berdampak positif bagi warga, khususnya ibu rumah tangga. Kelompok ibu rumah tangga menjadi sangat penting dalam upaya mendukung tingkat konsumsi sayur dan buah pada anak usia sekolah dasar. Hasil kegiatan PKM Kartini et al. (2018) menunjukkan bahwa penerapan teknologi budidaya tanaman sayur dan buah serta pengolahan pascapanennya pada kelompok ibu rumah tangga dapat meningkatkan pengetahuan ibu rumah tangga terhadap kegiatan menanam dan berdampak pada peningkatan taraf ekonomi dengan produk makanan es krim sayur yang dihasilkan. Begitu pula kegiatan PKM yang dilakukan Agustina et al (2014) dan Khairani et al (2018) yang menunjukkan bahwa kegiatan pascapanen produk pertanian terhadap kelompok ibu rumah tangga berdampak positif terhadap taraf ekonomi keluarga.

Merujuk kepada beberapa kegiatan PKM yang telah dijabarkan, maka solusi terhadap empat permasalahan yang dihadapi SDN Karangsalam diyakini dapat diatasi dengan penerapan kegiatan budidaya dan pascapanen tanaman sayuran dengan siswa sebagai khalayak sasaran. Oleh karena iti, kegiatan PKM ini bertujuan menerapkan teknologi budidaya tanaman sayuran dengan sistem demonstrasi dan plot (demplot), melakukan transfer pengetahuan beragam jenis sayur dan manfaatnya, dan show off produk makanan berbahan dasar sayur.

\section{BAHAN DAN METODE}

Kegiatan dilaksanakan selama delapan bulan sejak Maret sampai Oktober 2018 bertempat di lingkungan SDN Karangsalam. Bahan yang digunakan dalam kegiatan PKM ini adalah benih tanaman sayur seperti kangkung, bayam merah, pakcoy, caisim, dan selada merah (panah merah, east west seed). Peralatan yang digunakan adalah perangkat vertikultur model rak ukuran 2x1,5 meter (panjang x tinggi) sebanyak 2 buah dan model paralon ukuran 1,5 meter (tinggi) sebanyak 6 buah. Untuk perangkat vertikultur model rak memiliki 50 buah pot, sedangkan model paralon memiliki 108 buah lubang tanam.

Metode yang dilaksanakan, yaitu demplot dan pelatihan teknik budidaya tanaman sayur, kegiatan transfer pengetahuan tentang beragam jenis sayur dan manfaatnya, serta show off produk makanan berbahan dasar sayur yang disukai anak-anak seperti es krim sayur, nugget sayur, makaroni saus bolognise, risol sayur, jus sayur-buah, dan burger sayur.

\section{HASIL DAN PEMBAHASAN}

\subsection{Demplot Dan Pelatihan Teknik Budidaya Tanaman Sayur}

Kegiatan demplot dan pelatihan melibatkan siswa kelas V SDN Karangsalam sebagai khalayak sasaran. Pelatihan teknik budidaya meliputi, pelatihan teknik penyemaian, teknik persiapan media tanam, teknik penanaman bibit, teknik pemeliharaan bibit berbasis pertanian organik, dan teknik pemanenan. Tahap persemaian diawali dari penyiapan media semai. Media semai terdiri atas tanah top soil, pupuk kompos, sekam dengan perbandingan 1:1:1. Benih sayuran disemai dalam tray. Untuk benih kangkung dan bayam ditanam 2 buah per lubang tray, untuk pakcoy, selada, dan caisim ditanam 2-3 buah per lubang tray (Gambar 1).

Tahap penyemaian dilanjutkan dengan pemeliharaan benih yang disemai sehingga tumbuh menjadi bibit. Pemeliharaan meliputi penyiraman secukupnya menggunakan sprayer, dan dijauhkan dari sinar matahari langsung dan air hujan.

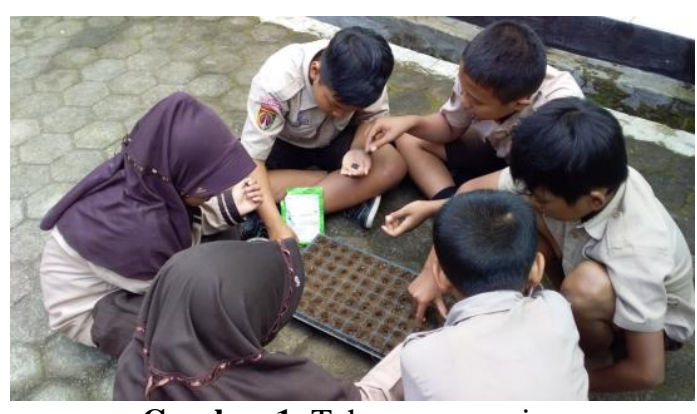

Gambar 1. Tahap persemaian

Bibit berumur 14 hari setelah semai (hss) yang tumbuh baik dan sehat (Gambar 2), selanjutnya ditanam. Tahap penanaman diawali dengan persiapan media tanam berupa campuran tanah dan pupuk kompos dengan perbandingan 1:1. Campuran tanah dan pupuk kompos dihomogenkan sebelum dipindahkan ke dalam pot. 


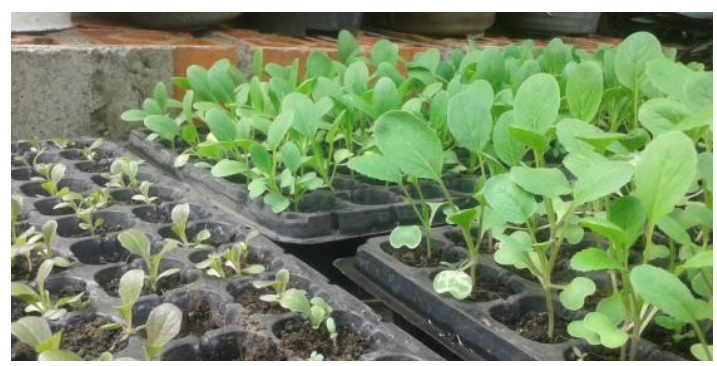

Gambar 2. Bibit selada merah, pakcoy, dan caisim berumur 14 hss siap ditanam

Setelah media tanam siap dalam pot atau paralon, bibit umur 14 hss dipilih untuk ditanam. Memindahkan bibit dari wadah persemaian (tray) ke dalam pot atau paralon sebaiknya dilakukan pagi hari atau sore hari untuk mengurangi stress tanaman terhadap suhu matahari. Untuk media pot berdiameter $20 \mathrm{~cm}$, bibit kangkung dapat ditanam 3-5 buah. Untuk bibit pakcoy, selada merah atau caisim 2-3 buah per pot, sedangkan bibit bayam merah 1-2 buah per pot. Untuk paralon dapat ditanam 1-2 bibit per lubang (Gambar 3).

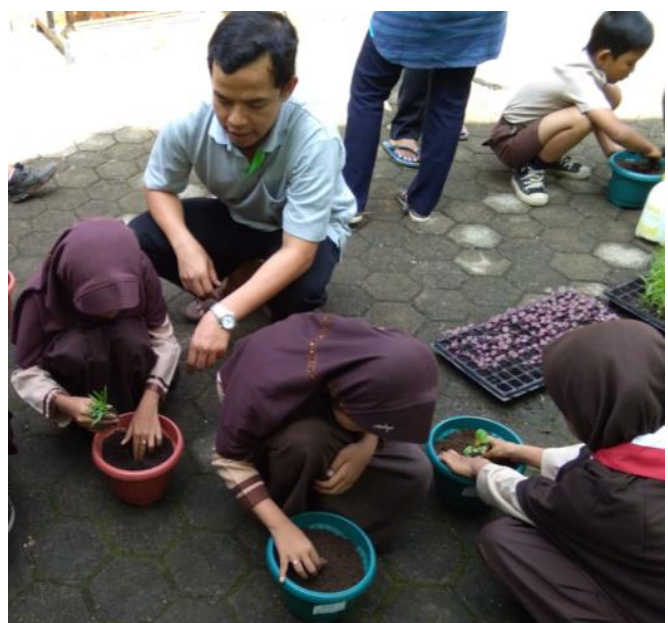

Gambar 3. Tahap penanaman bibit pada media tanam yang sudah disiapkan

Tahap berikutnya adalah pemeliharaan bibit. Tahap pemeliharaan yang dilakukan seperti penyiraman secara rutin $2 \mathrm{x}$ sehari (pagi-sore), pemberian pupuk organik cair $1 \mathrm{x}$ seminggu, penyiangan gulma dengan intensitas bergantung kuantitas gulma yang tumbuh, penyulaman tanaman sayur apabila terlihat layu atau mati pada umur tanaman maksimal 7 hari setelah tanam (hst), pengendalian hama dan penyakit yang mungkin menyerang tanaman menggunakan biopestisida atau pestisida nabati (Gambar 4).

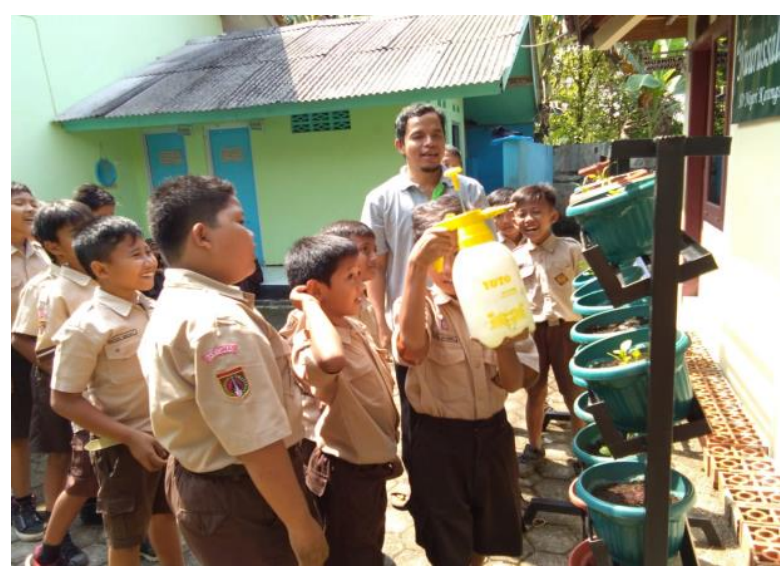

Gambar 4. Tahap pemeliharaan (penyiraman)

Tanaman yang dipelihara dengan baik akan tumbuh dan berkembang dengan subur (Gambar 5 dan 6).

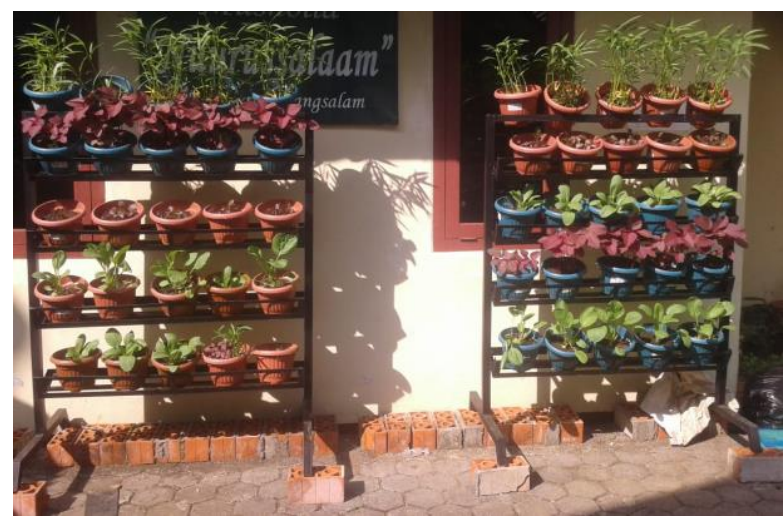

Gambar 5. Tanaman sayur dalam vertikultur model rak tumbuh dan berkembang dengan baik

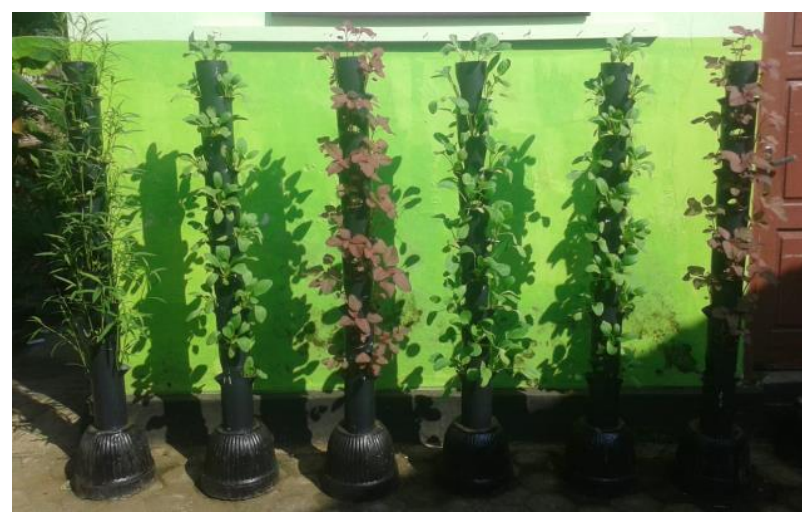

Gambar 6. Tanaman sayur dalam vertikultur model paralon tumbuh dan berkembang dengan baik

Tahap terakhir pelatihan teknik budidaya tanaman sayur adalah pemanenan. Pemanenan untuk tanaman kangkung, caisim, pakcoy, dan selada air dapat dilakukan saat tanaman berumur 30 hst. Untuk tanaman bayam dapat dipanen setelah tanaman berumur 45 hst. Pemanenan tanaman sayur dilakukan dengan cara memotong bagian batang berjarak $5 \mathrm{~cm}$ dari pangkal. Pemanenan dapat pula dilakukan dengan mencabutan tanaman. Untuk aplikasi di sekolah, pemanenan dengan pemotongan dapat lebih dipertimbangkan karena lebih 
efisien dalam penggunaan benih, pembuatan media semai dan tanam, serta penanaman.

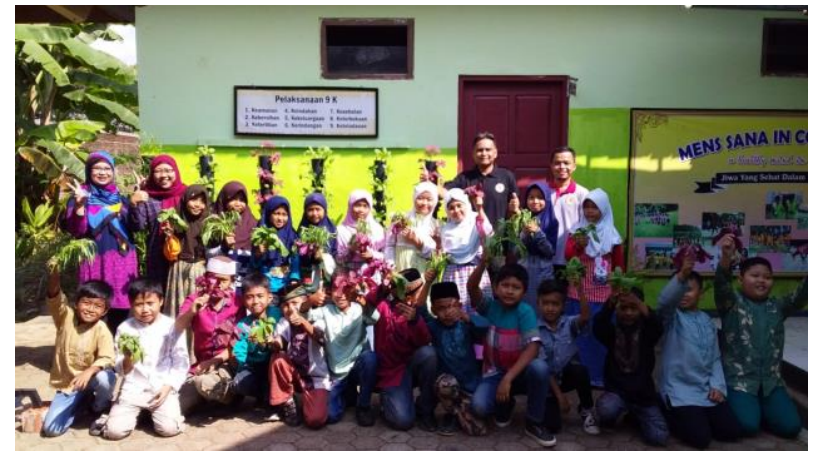

Gambar 7. Tim PKM bersama siswa setelah kegiatan pemanenan

\subsection{Kegiatan Transfer Pengetahuan Tentang Beragam Jenis Sayur Dan Manfaatnya}

Kegiatan ini bertujuan untuk menambah pengetahuan dan wawasan siswa terhadap beragam jenis sayur dan manfaat yang terkandung di dalamnya khususnya untuk anak usia sekolah. Kegiatan dilakukan melalui presentasi tim PKM kepada khalayak sasaran (Gambar 8).

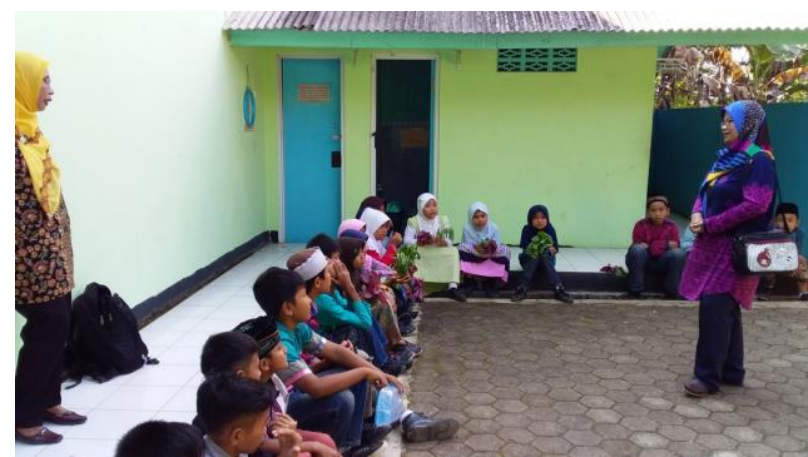

Gambar 8. Transfer pengetahuan beragam jenis sayur dan manfaatnya

\subsection{Show Off Produk Makanan Berbahan Dasar Sayur}

Kegiatan ini bertujuan untuk meningkatkan pengetahuan siswa tentang beragam jenis makanan berbahan sayur. Dengan kegiatan ini, kesukaan dan frekuensi siswa mengkonsumsi makanan berbahan sayur diharapkan mengalami peningkatan. Produk makanan berbahan dasar sayur yang ditampilkan berupa berupa es krim sayur, nugget sayur, makaroni saus bolognise, risol sayur, jus sayur-buah, dan burger sayur (Gambar 9).
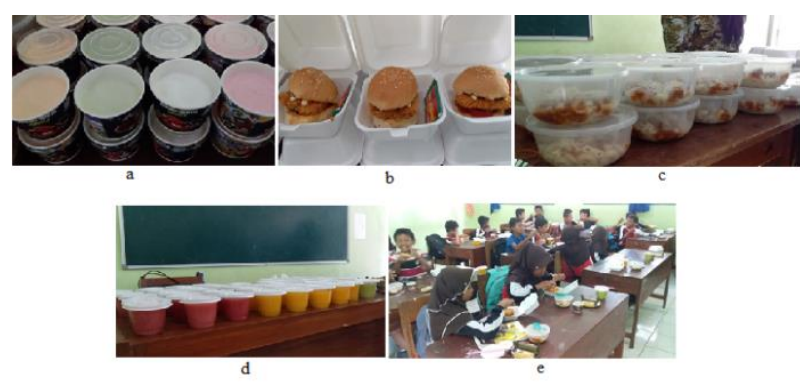

Gambar 9. Show off aneka produk makanan berbasis sayur. a. Es krim sayur, b. Burger isi nuget sayur, c. Makaroni saus bolognise isi sayur, d. Jus sayur-buah, e. Siswa menikmati produk makanan berbahan sayur.

\subsection{Perbandingan Hasil Pre-Test dan Post-Test}

Untuk mengetahui dampak kegiatan PKM terhadap pengetahuan dan keterampilan, siswa diberikan sejumlah pertanyaan dalam pre-test dan post-test. Pretest dilaksanakan sebelum pelaksanaan kegiatan PKM, sedangkan post-test diberikan setelah semua kegiatan dilaksanakan. Hasil pre-test dan post-test diperbandingkan untuk menilai tingkat keberhasilan kegiatan PKM.

Pertanyaan pertama adalah apakah siswa pernah melakukan kegiatan menanam tanaman sayuran. Perbandingan jawaban pre-test dan post-test menunjukkan terjadi peningkatan dari $75 \%$ siswa yang pernah menanam tanaman sayuran sebelum kegiatan PKM menjadi 100\% setelah kegiatan PKM (Gambar $10)$.

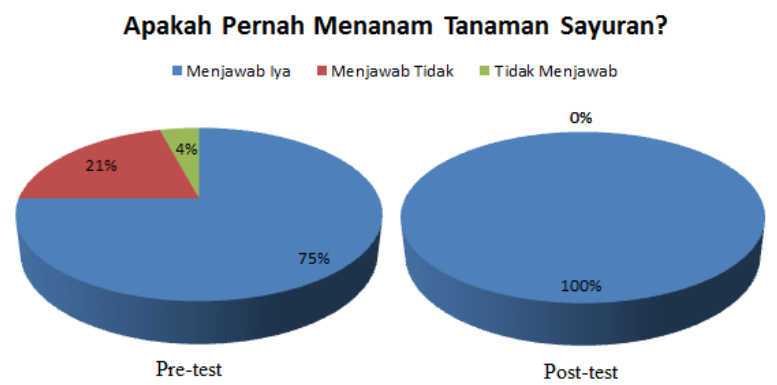

Gambar 10. Pertanyaan pre-test dan post-test terkait pernah tidaknya siswa menanam tanaman sayuran.

Ditinjau dari tanaman sayuran apa yang pernah ditanam siswa, maka ada perubahan antara jawaban pre-test dan post-test. Tanaman kangkung mengalami peningkatan dari $14 \%$ menjadi $46 \%$, sedangkan tanaman bayam mengalami penurunan dari $48 \%$ menjadi $23 \%$. Tanaman caisim dan pakcoy juga mengalami peningkatan dari sebelumnya tidak pernah ditanam menjadi $11 \%$. Persentase siswa yang tidak menjawab juga berkurang dari $28 \%$ sebelum kegiatan PKM menjadi hanya $6 \%$ setelah kegiatan PKM. Ini menunjukkan bahwa kegiatan menanam dalam PKM ini direkam dengan baik oleh siswa (Gambar 11). 


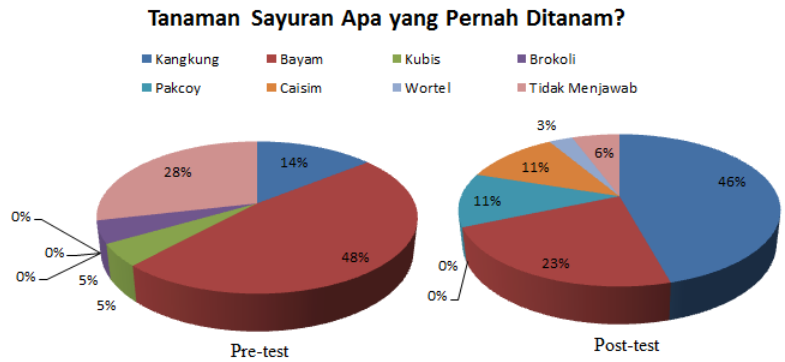

Gambar 11. Pertanyaan pre-test dan post-test terkait jenis tanaman sayuran apa yang pernah ditanam.

Pertanyaan berikutnya, apakah siswa mengetahui budidaya tanaman sayuran dengan teknik vertikultur. Sebelum kegiatan PKM, 96\% siswa tidak mengetahui teknik vertikultur, setelah kegiatan PKM, persentase siswa yng tidak mengetahui teknik vertikultur menurun hanya tinggal 29\%. Setelah kegiatan PKM 71\% siswa menjawab mengetahui teknik vertikultur, padahal sebelumnya tidak ada yang mengetahui teknik ini (Gambar 12).

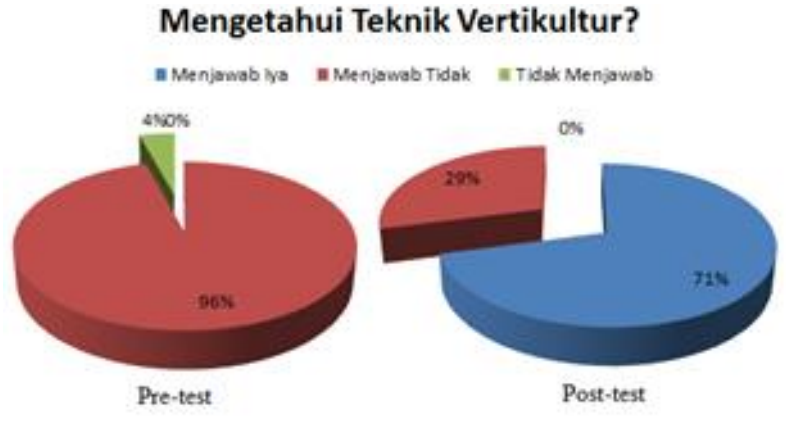

Gambar 12. Pertanyaan pre-test dan post-test terkait pengetahuan siswa terhadap teknik vertikultur.

Dilihat dari jawaban siswa terhadap pertanyaan apakah pernah menanam sayuran dengan teknik vertikultur, maka diperoleh data bahwa sebelum kegiatan PKM siswa yang menjawab YA hanya 4\%, sisanya menjawab TIDAK 92\% dan tidak menjawab $4 \%$. Setelah kegiatan PKM ada perubahan. Siswa yang menjawab YA meningkat menjadi $42 \%$, tidak ada siswa yang tidak menjawab, dan terjadi penurunan jawaban TIDAK menjadi 58\%. Ini menunjukkan bahwa kegiatan menanam sayuran dengan teknik vertikultur dapat dipahami dengan cukup baik oleh siswa (Gambar 13).

Pernah Menanam Sayuran dengan Teknik Vertikultur?

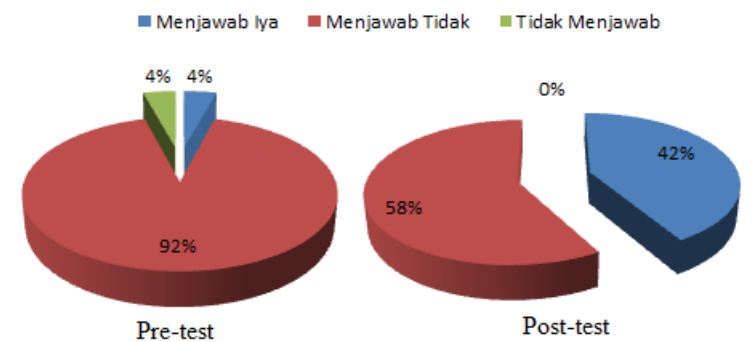

Gambar 13. Pertanyaan pre-test dan post-test terkait pernah atau tidak menanam tanaman sayuran menggunakan teknik vertikultur.
Pertanyaan berikutnya untuk mengukur pengetahuan siswa sebelum dan sesudah kegiatan PKM terkait pengetahuan siswa terhadap ragam jenis sayuran. Siswa diminta menjawab beberapa gambar tanaman sayuran yang ditampilkan dalam soal pre-test dan post-test. Hasil menunjukkan sebelum kegiatan PKM, 8\% siswa tidak menjawab sama sekali, $13 \%$ menjawab hanya 1 gambar, siswanya $71 \%$ menjawab 2 gambar. Tidak ada satupun siswa yang bisa menjawab dengan benar 3 dan 4 gambar. Setelah kegiatan PKM, persentase sebagian besar siswa $92 \%$ menjawab 3 gambar dengan benar, sisanya $4 \%$ menjawab 2 gambar, dan $4 \%$ menjawab 1 gambar. Hal ini menunjukkan bahwa terjadi peningkatan pengetahuan siswa terhadap ragam jenis sayur melalui kegiatan ini (Gambar 14).

\section{Menjawab dengan Benar Gambar Tanaman Sayuran}

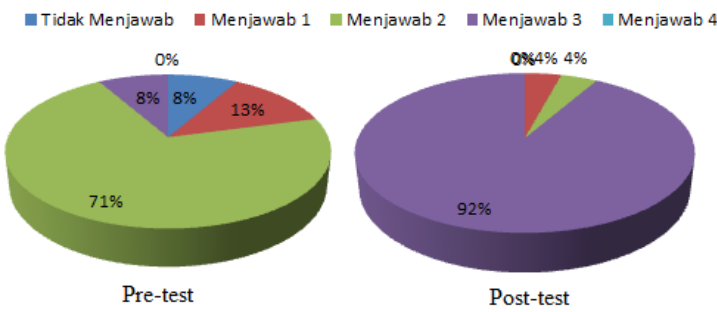

Gambar 14. Pertanyaan pre-test dan post-test terkait pengetahuan siswa terhadap ragam jenis sayur.

Terkait pengetahuan siswa terhadap manfaat sayuran bagi kesehatan, dalam soal pre-test dan post-test disediakan lima kolom yang dapat diisi oleh siswa. Perbandingan hasil pre-test dan post-test menunjukkan terjadi peningkatan kemampuan siswa menjawab 5 kolom dengan benar dari $0 \%$ sebelum kegiatan menjadi $62 \%$ setelah kegiatan. Kemampuan siswa menjawab 4 kolom dengan benar juga mengalami peningkatan dari $8 \%$ menjadi $17 \%$ (Gambar 15).

Manjawab dengan Benar Manfaat Sayuran Bagi Kesehatan?

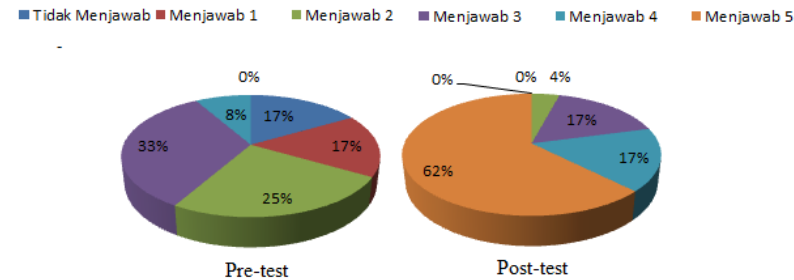

Gambar 15. Pertanyaan pre-test dan post-test terkait pengetahuan siswa terhadap manfaat sayur bagi kesehatan.

Kegiatan PKM juga menggali ketertarikan siswa terhadap kegiatan budidaya tanaman sayuran sebelum dan sesudah kegiatan PKM. Dari hasil yang disajikan pada Gambar 16, terjadi peningkatan ketertarikan siswa dari $33 \%$ tertarik budidaya tanaman sayuran menjadi $46 \%$, begitu pula dari $21 \%$ sangat tertarik menjadi $33 \%$. Ini mengindikasikan bahwa kegiatan PKM yang dilakukan mampu meningkatkan ketertarikan siswa terhadap kegiatan budidaya tanaman sayuran. 


\section{Tertarik Budidaya Tanaman Sayuran?}

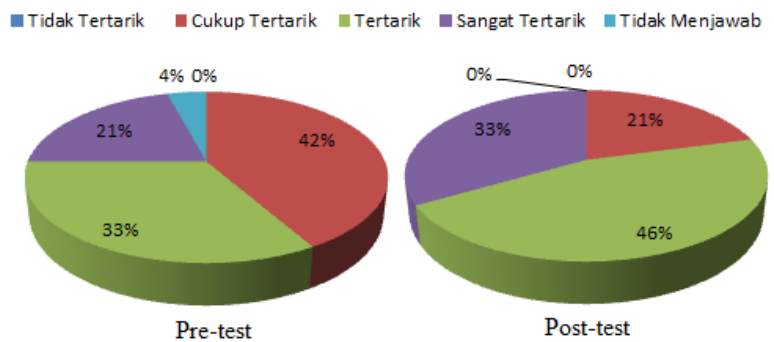

Gambar 16. Pertanyaan pre-test dan post-test terkait ketertarikan siswa terhadap budidaya tanaman sayuran.

Kesukaan siswa terhadap makanan berbahan sayuran sebelum dan sesudah kegiatan PKM juga dilihat (Gambar 17). Sebelum kegiatan, terdapat $4 \%$ siswa yang tidak suka makanan berbahan sayuran dan $4 \%$ tidak menjawab. Setelah pelaksanaan kegiatan PKM, tidak ada siswa yang menjawab tidak suka atau tidak menjawab. 100 persen siswa suka makanan berbahan sayuran. Hal menunjukkan bahwa kegiatan PKM berhasil meningkatkan kesukaan siswa terhadap makanan berbahan sayuran.

\section{Suka Makanan Berbahan Sayuran?}
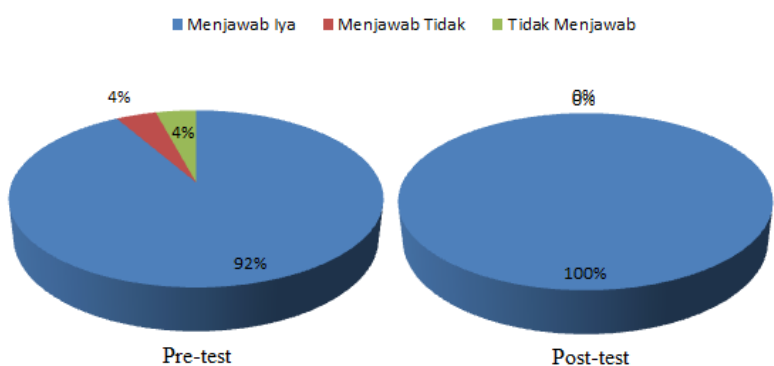

Gambar 17. Pertanyaan pre-test dan post-test terkait kesukaan siswa terhadap makanan berbahan sayuran

Frekuensi konsumsi makanan berbahan sayuran sebelum dan sesudah kegiatan PKM disajikan dalam Gambar 18 . Frekuensi siswa yang mengkonsumsi sayuran setiap hari meningkat dari $42 \%$ menjadi $71 \%$, sedangkan frekuensi konsumsi $3 \mathrm{x}$ seminggu meningkat dari $17 \%$ menjadi $21 \%$. Hal ini menunjukkan kegiatan PKM yang dilakukan mampu mendorong frekuensi konsumsi makanan berbahan sayuran pada siswa.

\section{Frekuensi Konsumsi Makanan Berbahan}

\section{Sayuran?}

- Setiap Hari $\mathbf{m}$ 3x Seminggu $\|$ 2x Sem inggu $\|$ 1x Sem inggu $\|$ Tidak Menjawab
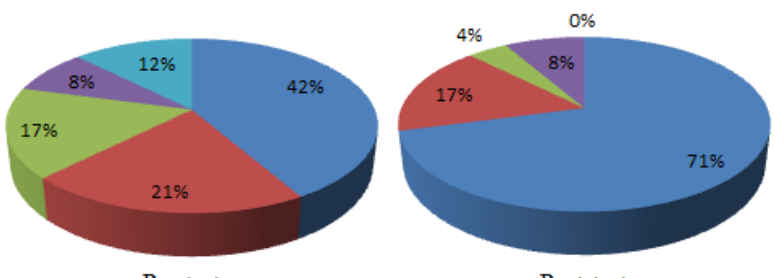

Pre-test

Gambar 17. Pertanyaan pre-test dan post-test terkait frekuensi siswa mengkonsumsi makanan berbahan sayuran

\section{KESIMPULAN}

Kegiatan PKM yang dilaksanakan berhasil menerapkan teknologi budidaya tanaman sayuran menggunakan teknik vertikultur dengan sistem demplot, transfer pengetahuan beragam jenis sayur dan manfaatnya dapat dilaksanakan dengan baik. Kegiatan PKM ini juga berhasil menampilkan (show off) produk-produk makanan berbahan sayuran seperti es krim sayur, nugget sayur, makaroni saus bolognise, risol sayur, jus sayur-buah, dan burger sayur. Kegiatan PKM diikuti secara antusias oleh khalayak sasaran, siswa kelas V SDN Karangsalam.

Dalam jangka pendek, kegiatan PKM ini berhasil meningkatkan pengetahuan dan keterampilan siswa dalam budidaya tanaman sayuran menggunakan teknik vertikultur, meningkatkan pengetahuan siswa terhadap ragam hebus sayur dan manfaatnya, meningkatkan ketertarikan siswa dalam budidaya tanaman sayuran, meningkatkan kesukaan siswa terhadap makanan berbahan sayuran, serta meningkatkan frekuensi harian siswa mengkonsumsi makanan berbahan sayuran. Implikasi jangka pendek tergambar pada perbandingan hasil pre-test dan post-test.

Dalam jangka panjang, kegiatan PKM mampu memberikan kontribusi positif untuk menjawab permasalahan di SDN Karangsalam. Keberadaan demplot vertikultur dapat mendukung upaya sekolah menjadi sekolah adiwiyata serta menjadi percontohan bagi lingkungan masyarakat di sekitar sekolah.

\section{UCAPAN TERIMA KASIH}

Ucapan terima kasih disampaikan kepada Lembaga Penelitian dan Pengabdian Masyarakat Universitas Jenderal Soedirman atas dukungan dana yang diberikan.

\section{DAFTAR PUSTAKA}

Agustina, T., Kusmiati, A., \& Puspaningrum, D. (2014). IBM Kelompok Ibu Rumah Tangga Usaha Aneka Pengolahan Pisang. Laporan Akhir Ipteks Bagi Masyarakat.

Khairani, Z., Kamilah, F., \& Aznuriyandi. (2018). Peningkatan Daya Saing Produk Melalui Kreasi Makanan Berbahan Baku Hasil Pertanian Lokal. Jurnal bakti saintek, 2 (1), 1116.

Kartini, Harjoso, T., \& Anwar, S. (2015). Berkebun Sayur dan Buah Organik dengan Teknik Vertikultur pada Kelompok Anak Sekolah Dasar. Laporan Akhir Ipteks Bagi Masyarakat.

Kartini, Harjoso, T., \& Hadi, S.N. 2018. Penerapan Teknologi Budidaya dan Pengolahan Pascapanen Sayur dan Buah Pada Kelompok Ibu Rumah Tangga di Desa Karangsalam Kidul Kabupaten Banyumas. JPKM, 24 (2), 684-688.

Hadi, S.N., Ahadiyat, Y.R., \& Widiyawati, I. (2017). Penerapan teknologi berkebun sayur secara vertikultur pada siswa sekolah dasar di Purwokerto Jawa Tengah. Panrita Abdi, 1(2), 44-49. 